\title{
Analysis of the Technical Content of Elite Rhythmic Gymnastics Group Routines
}

\author{
Lurdes Ávila-Carvalho*, Maria da Luz Palomero, Panaginota Klentrou and Eunice Lebre
}

Department of Gymnastics, Faculty of Sports, Porto University, Porto, Portugal

\begin{abstract}
The purpose of this study was to analyse all technical elements used in elite Rhythmic Gymnastics group routines. All technical difficulties reported in the forms submitted during the 2007, 2008, 2009 and 2010 Portimão World Cup competitions were analysed. These included a total of 126 different Group routines from 28 countries. The Groups were clustered for the analysis into two subgroups according to their ranking at the 2010 World Championship. The body difficulties were organized according to the new technical framework into four technical element categories including balances, jumps, rotations and exchange difficulties. Body difficulties in Rhythmic Gymnastics group routines followed a pattern consistent with their ranking. The main characteristic of the routine composition was the focus on exchanges, balances and jumps and the lesser use of rotations. Amongst all body difficulties, the jumps was the technical category with the most limited variety while rotations although less used had more variety. The limited variety in the choice of body difficulties in the composition of Rhythmic Gymnastics group routines makes them monotonous and compromises their artistic value. This study provides updated information regarding the mainstream strategies in the Rhythmic Gymnastics routine composition.
\end{abstract}

Keywords: Body difficulty, elite rhythmic gymnastics, group routines, evaluation.

\section{INTRODUCTION}

Traditionally, technical studies in gymnastics disciplines have been based on the Code of Points. However, according to Bauch [1] the analysis of competition routines must be focused more on the qualitative content rather than the Code of Points rules, allowing different approaches in the routine composition. According to Bobo \& Sierra [2] the physical difficulty presented by International Federation of Gymnastics (FIG) is ambiguous and does not define appropriate criteria based actions executed by the gymnasts. Movements that involve different qualitative and quantitative requirements are often seen running within the same category or level of difficulty, hence the lack of variety in the compositions.

The new principles of technical movement elements proposed by Lebre [3] to be adopted by FIG in the new Olympic cycle (2013-2016) is based on scientific evidence [3], and allows a better analysis of the routine content. The new classification was based on the basic movement skills and on the level of technical difficulty and complexity in Rhythmic Gymnastics [3]. This way, the technical movement elements were classified into three major categories: balances, jumps and rotations. This classification is consistent with Russel's [4] movement analysis according to which the gymnastics actions are divided into stationary

*Address correspondence to this author at the Department of Gymnastics, Faculty of Sports, Porto University, Porto, Portugal;

Tel: 962483462-915919013; Fax: +351225500689;

E-mails: lurdesavila@fade.up.pt, lurdesavila4@hotmail.com and non-stationary positions. The stationary positions were further subdivided into support, balance and suspension positions. In Rhythmic Gymnastics, however, only the balance positions are classified in the Code of Points as technical elements. The non-stationary positions are subdivided by Russel [4] into linear (jumps and locomotion) and rotational movements (rotations and swings). In Rhythmic Gymnastics only jumps and rotation movements are considered difficulty elements by the Code of Points. Therefore, Lebre [3] based the new Rhythmic Gymnastics technical movement elements on the fundamental movement skills that are consistent across all gymnastics disciplines. This consistency between the FIG technical curriculum [5] and the Code of Points is important for the integration of coaching and judging principles and competences.

Strategies employed in the composition of Rhythmic Gymnastics routines follow the international trends of the sport in improving the harmony, dynamism, originality, beauty and increased risks [6]. The increased complexity of elements and routines, and the interaction between the gymnast and the apparatus are, according to Lisistskaya [7], the main characteristics of Rhythmic Gymnastics. In group routines the success is achieved when there is a high degree of movement synchrony, ample use of space and a balanced and emotional expression through different group formations. However, very few studies have analyzed the difficulty elements used in routines [8-16], and the technical value of elite Rhythmic Gymnastics group routines. According to Caburrasi \& Santana [13], it is more important to study the difficulty value than the total number of difficulty elements in the routine. In this case, only one study by Salvador [16] has evaluated the difficulty value of 
Table 1. Classes of Difficulties Per Technical Category

\begin{tabular}{|c|c|c|c|}
\hline Exchanges & Balances & Jumps & Rotations \\
\hline \multirow{7}{*}{$\begin{array}{l}\text { (b) With body difficulty: } \\
\text { balances, jumps and rotations }\end{array}$} & (b) Free leg at horizontal & (b) Split and Stag & (b) Rotations on flat foot \\
\hline & (c) Dynamic on different body parts & (c) Cossack & (c) Free leg at horizontal \\
\hline & (d) Fouetté & (d) Arch and Cabriole & (d) Free leg high \\
\hline & (f) Free leg below horizontal & (f) Fouetté & (f) Rotations on body parts \\
\hline & (g) Bent support leg & (g) Pike and Straddle & (g) Free leg below horizontal \\
\hline & (h) Static on different body parts & (h) Ring & (h) Rotations with shape change \\
\hline & & $\begin{array}{l}\text { (i) Others: Split and Stag with change } \\
\text { legs, Scissor, Enterlacé and Butterfly }\end{array}$ & \\
\hline
\end{tabular}

Table 2. Number of Exchange Difficulties Presented in the Rhythmic Gymnastics Group Routines Clustered According to their Position in the 2010 World Championship Ranking

\begin{tabular}{|c|c|c|c|c|c|c|c|c|}
\hline & \multicolumn{3}{|c|}{ First half in Ranking (n=96) } & \multicolumn{4}{c|}{ Second Half in Ranking (n=30) } \\
\hline Difficulty Number & Mean & sd & min & max & Mean & sd & min & max \\
\hline \hline Exchange difficulties & $6.74 *$ & 0.85 & 5 & 10 & 6.27 & 0.64 & 5 & 8 \\
\hline \hline
\end{tabular}

$* \mathrm{p}<0.05$

Rhythmic Gymnastics individual routines while there has been no published data on the technical content of elite Rhythmic Gymnastics group routines. Therefore, the purpose of this study was to analyse the technical difficulties used in the group routines at the 2007, 2008, 2009 and 2010 Portimão World Cup competitions both from a quantitative and qualitative perspective.

\section{METHODS}

\section{Subjects and Design}

A hundred twenty six group routines from 28 countries competing at the Rhythmic Gymnastics World Cup in Portimão, Portugal in 2007, 2008, 2009 and 2010 were analysed. All the groups participating in these competitions were invited and gave consent to participate in the study. This study was approved by the Scientific Committee of FIG.

All body difficulties reported in the technical forms provided at the competition were analysed. The groups were clustered into two subgroups according to their 2010 World Championship ranking. Body difficulty elements were organized according to the new technical framework by Lebre [3] into four technical element categories including balances, jumps, rotations and exchange difficulties (Table 1).

\section{Statistical Analysis}

For the statistical analysis we used the Statistical Package for the Social Sciences - Version 17.0 (SPSS 17.0, Chicago, USA) and Microsoft Office Excel 2007. Descriptive statistics were calculated using the mean values as a measure of central tendency, standard deviation (sd) as a measure of dispersion, and minimum and maximum as measures of data range. After checking the normality of the data distribution using the Kolmogorov-Smirnov test we used a t-test to determine whether there were significant differences between the sub groups of the first $(n=96)$ and second half $(n=30)$ in the 2010 World Championship ranking. A level less than 0.05 was used as a criterion for significance.

\section{RESULTS}

The difficulty elements reported in the group routines were clustered in four technical categories: exchanges, balances, jumps and rotations. The results for each category are presented both quantitatively (number of occurrences) and qualitatively (technical value of the difficulties according to the FIG Code of Points [17, 18]). The routines ranked in the first, top half had significantly higher number of exchange difficulties number as compared to the routines of the second, lower half (Table 2) but there were no other significant differences in the number of technical difficulties according to the ranking position (Fig. 1). As shown in Fig. (1), however, both groups had higher number of balance and jump difficulties while the rotation difficulties were the category less used in all routines.

There was a significant difference also in the technical value of the exchange and rotation difficulties between the routines of the first versus the second half in the World ranking (Table 3). However, although the routines in the first, top half showed a higher value of balance and jump difficulties than those in the second half of the ranking these differences were not significant (Fig. 2).

\section{Exchange Difficulties}

As shown in Fig. (3), no significant difference was found in the number of exchange difficulties between the routines of the first versus those of the second half of the World ranking. However, although not significant the routines of 


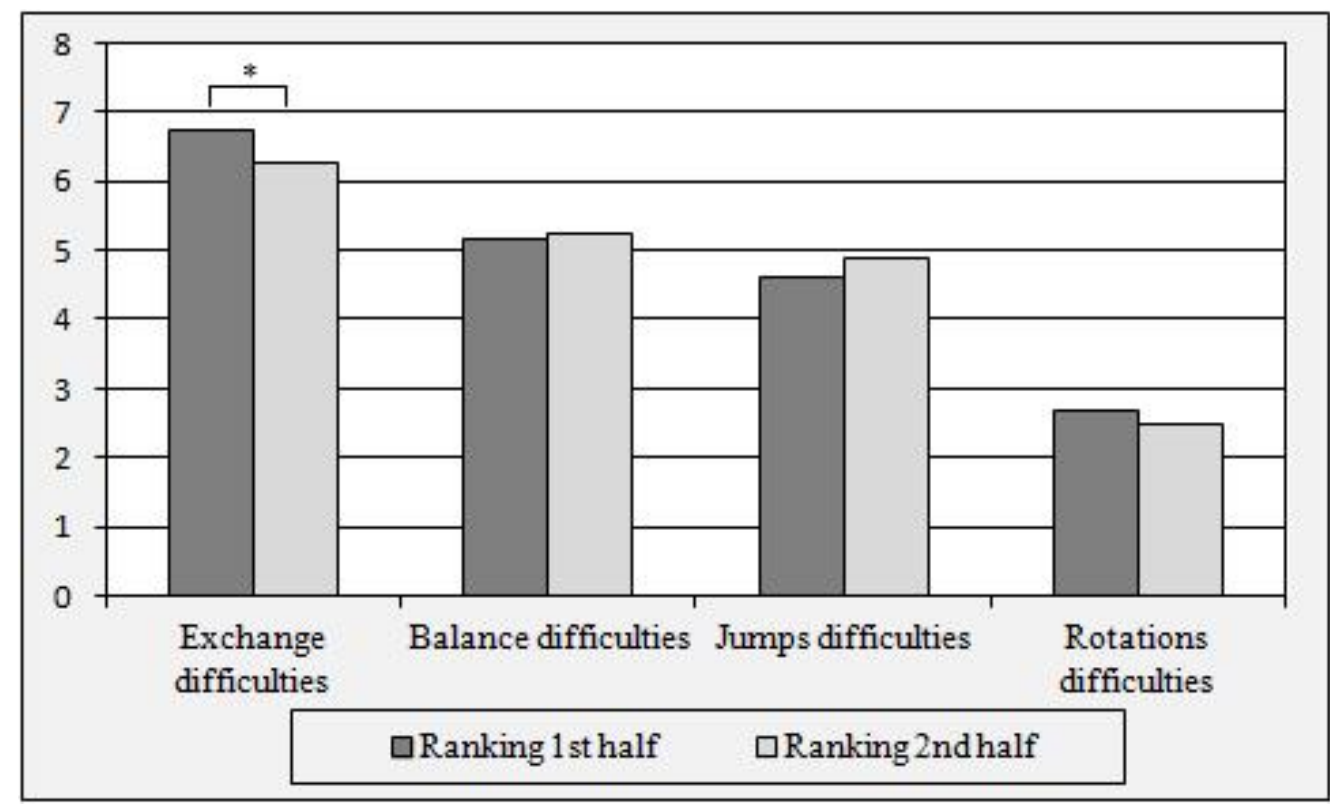

Fig. (1). Number of difficulties presented in the Rhythmic Gymnastics group routines clustered according to their position in the 2010 World Championship ranking $\left({ }^{*} \mathrm{p}<0.05\right)$.

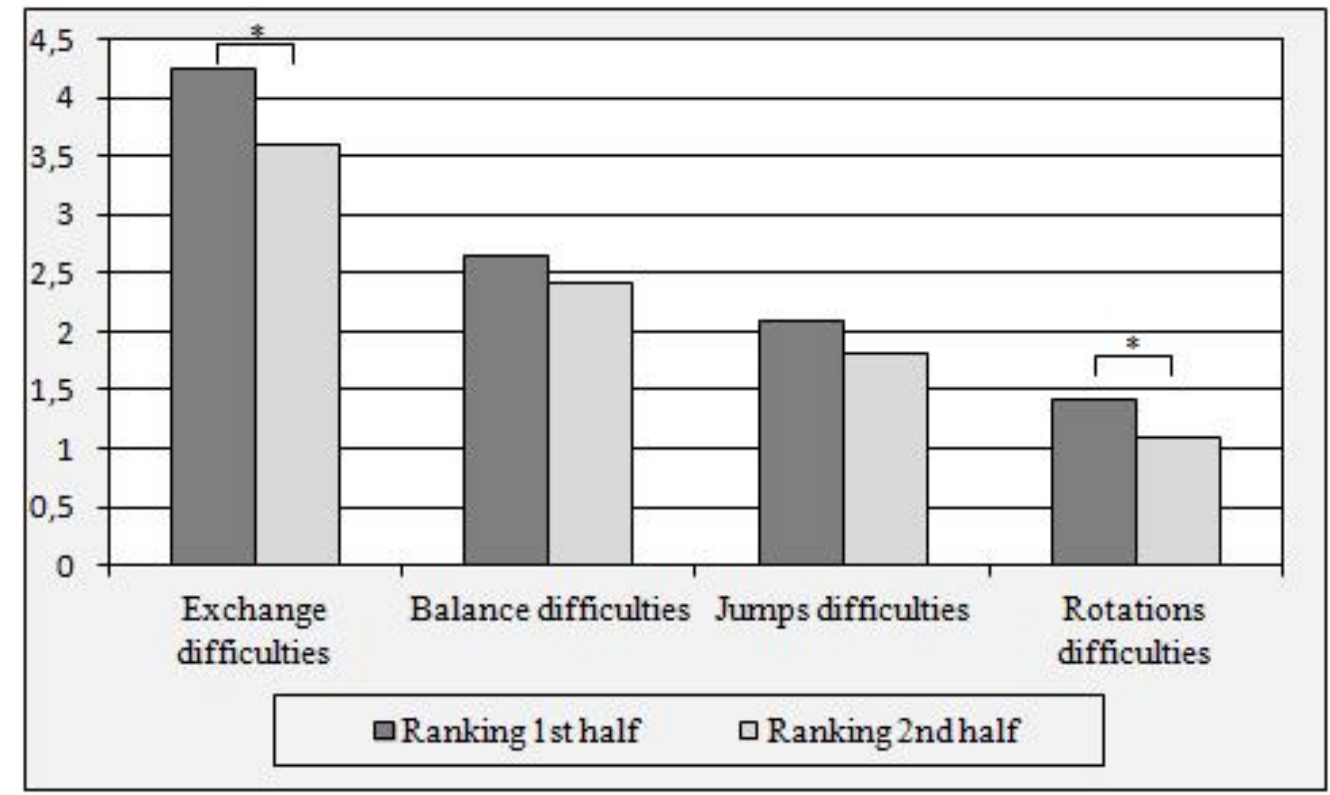

Fig. (2). Technical value of the difficulties presented in the Rhythmic Gymnastics group routines clustered according to their position in the 2010 World Championship ranking $(* \mathrm{p}<0.05)$.

Table 3. Technical Value of Exchange and Rotation Difficulties Presented in the Rhythmic Gymnastics Group Routines Clustered According to their Position in the 2010 World Championship Ranking

\begin{tabular}{|c|c|c|c|c|c|c|c|c|}
\hline & \multicolumn{3}{|c|}{ First Half in Ranking (n=96) } & \multicolumn{4}{c|}{ Second Half in Ranking (n=30) } \\
\hline Difficulty value & Mean & sd & min & max & Mean & sd & min & max \\
\hline \hline Exchange difficulties & $4.24 *$ & 0.93 & 2.20 & 7.10 & 3.59 & 0.98 & 2.10 & 6.30 \\
\hline Rotation difficulties & $1.42^{*}$ & 0.75 & 0.00 & 3.50 & 1.09 & 0.53 & 0.00 & 2.10 \\
\hline
\end{tabular}

${ }^{*} \mathrm{p}<0.05$

the first half included more exchanges without body difficulties (3.90 \pm 2.20 vs. 3.43 \pm 1.68 , respectively) and with body difficulties $(2.84 \pm 1.88 v s .2 .83 \pm 1.84)$ than those in the second half of the ranking. In addition, jumps were the movement category mostly used for the exchanges of both ranking groups with the rotations being the movement category less used but these differences were not significant (Fig. 3). 


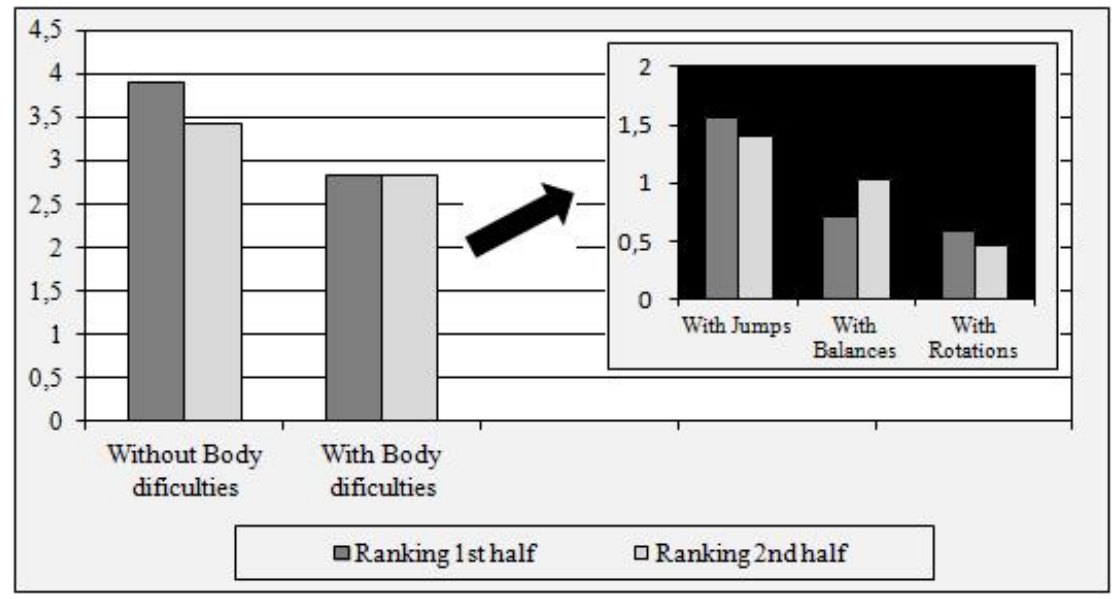

Fig. (3). Number of exchange difficulties with and without body difficulties presented in the Rhythmic Gymnastics group routines clustered according to their position in the 2010 World Championship ranking $(* \mathrm{p}<0.05)$.

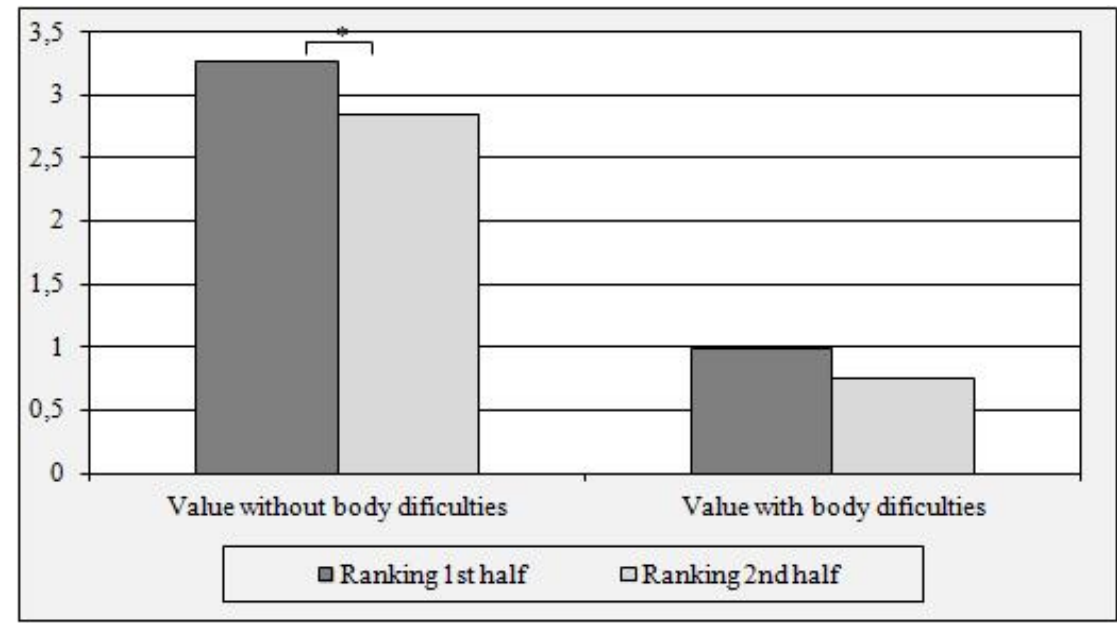

Fig. (4). Technical value of exchange difficulties with and without body difficulties presented in the Rhythmic Gymnastics group routines clustered according to their position in the 2010 World Championship ranking $\left({ }^{*} \mathrm{p}<0.05\right)$.

Table 4. Number of Balance Difficulties Presented in the Rhythmic Gymnastics Group Routines Clustered According to their Position in the 2010 World Championship Ranking

\begin{tabular}{|l|c|c|c|c|c|c|c|c|}
\hline & \multicolumn{3}{|c|}{ First Half in Ranking (n=96) } & \multicolumn{4}{c|}{ Second Half in Ranking (n=30) } \\
\hline \multicolumn{1}{|c|}{ Number of Balance Difficulties } & Mean & sd & min & max & Mean & sd & min & max \\
\hline \hline Free leg high (a) & $3.09^{*}$ & 1.03 & 0.00 & 6.00 & 2.37 & 1.65 & 0.00 & 6.00 \\
\hline Free leg at horizontal (b) & $1.16^{*}$ & 0.96 & 0.00 & 4.00 & 1.63 & 0.96 & 0.00 & 3.00 \\
\hline Dynamic on different body parts (c) & $0.55^{*}$ & 0.82 & 0.00 & 3.00 & 0.07 & 0.25 & 0.00 & 1.00 \\
\hline Dynamic with wave (e) & $0.14^{*}$ & 0.37 & 0.00 & 2.00 & 0.43 & 0.50 & 0.00 & 1.00 \\
\hline Bent support leg (g) & $0.00^{*}$ & 0.00 & 0.00 & 0.00 & 0.27 & 0.52 & 0.00 & 2.00 \\
\hline
\end{tabular}

${ }^{*} \mathrm{p}<0.05$

On the other hand, the mean technical value of the exchanges without difficulties included in the routines ranked in the first half was significantly higher than the value of those used in the routines ranked in the second half but this was not the case with the exchanges with body difficulties (Fig. 4).

\section{Balance Difficulties}

There were significant differences in the number of balance difficulties between the routines of the first half and those in the second half of the World ranking (Table 4). The routines ranked in the first half had a higher number of class (a) and (c) balance difficulties. In contrast, the routines in the second half of the ranking had higher number of class (b), (e) and (g) balance difficulties (Table 4).

In addition, there were significant differences also in technical value of the balance difficulties presented in the routines ranked in the first half and those ranked in the second half of the World ranking. More specifically, the routines ranked in the first half had a higher difficulty value for balances in class (a) and (c) while the routines ranked in second half had higher value balances of class (e) and (g) (Table 5). 
Table 5. Technical Value of Balance Difficulties Presented in the Rhythmic Gymnastics Group Routines Clustered According to their Position in the 2010 World Championship Ranking

\begin{tabular}{|c|c|c|c|c|c|c|c|c|}
\hline \multirow[b]{2}{*}{ Value of Balance Difficulties } & \multicolumn{4}{|c|}{ First half in Ranking ( $n=96$ ) } & \multicolumn{4}{|c|}{ Second Half in Ranking ( $n=30)$} \\
\hline & Mean Values & sd & $\min$ & $\max$ & Mean values & sd & $\min$ & $\max$ \\
\hline Free leg high (a) & $1.65^{*}$ & 0.56 & 0.00 & 3.40 & 1.19 & 0.94 & 0.00 & 3.40 \\
\hline Dynamic on different body parts (c) & $0.32 *$ & 0.50 & 0.00 & 2.10 & 0.05 & 0.18 & 0.00 & 0.70 \\
\hline Dynamic with wave (e) & $0.06^{*}$ & 0.18 & 0.00 & 1.00 & 0.19 & 0.24 & 0.00 & 0.50 \\
\hline Bent support leg (g) & $0.00 *$ & 0.00 & 0.00 & 0.00 & 0.10 & 0.19 & 0.00 & 0.70 \\
\hline
\end{tabular}

*p $<0.05$

Table 6. Number of Jump Difficulties Presented in the Rhythmic Gymnastics Group Routines Clustered According to their Position in the 2010 World Championship Ranking

\begin{tabular}{|l|c|c|c|c|c|c|c|c|}
\hline & \multicolumn{3}{|c|}{ First Half in Ranking (n=96) } & \multicolumn{4}{c|}{ Second Half in Ranking (n=30) } \\
\hline \multicolumn{1}{|c|}{ Number of Jump Difficulties } & Mean & sd & min & max & Mean & sd & min & max \\
\hline \hline Jeté with turn (a) & $2.79^{*}$ & 1.04 & 0.00 & 5.00 & 2.17 & 1.12 & 0.00 & 4.00 \\
\hline Cossack (c) & $0.55^{*}$ & 0.60 & 0.00 & 2.00 & 1.00 & 0.79 & 0.00 & 2.00 \\
\hline Fouetté (f) & $0.04^{*}$ & 0.20 & 0.00 & 1.00 & 0.00 & 0.00 & 0.00 & 0.00 \\
\hline Pike and straddle (g) & $0.00^{*}$ & 0.00 & 0.00 & 0.00 & 0.13 & 0.35 & 0.00 & 1.00 \\
\hline
\end{tabular}

${ }^{*} \mathrm{p}<0.05$

Table 7. Technical Value of Jump Difficulties Presented in the Rhythmic Gymnastics Group Routines Clustered According to their Position in the 2010 World Championship Ranking

\begin{tabular}{|c|c|c|c|c|c|c|c|c|}
\hline & \multicolumn{3}{|c|}{ First Half in Ranking (n=96) } & \multicolumn{4}{c|}{ Second Half in Ranking (n=30) } \\
\hline Value of Jump Difficulties & Mean & sd & min & max & Mean & sd & min & max \\
\hline \hline Jeté with turn (a) & $1.42^{*}$ & 0.57 & 0.00 & 3.00 & 0.99 & 0.53 & 0.00 & 2.20 \\
\hline Arch and Cabriole (d) & $0.01 *$ & 0.03 & 0.00 & 0.10 & 0.03 & 0.08 & 0.00 & 0.30 \\
\hline Pike and Straddle (g) & $0.00^{*}$ & 0.00 & 0.00 & 0.00 & 0.07 & 0.19 & 0.00 & 0.60 \\
\hline
\end{tabular}

${ }^{*} \mathrm{p}<0.05$

Table 8. Number of Rotation Difficulties Presented in the Rhythmic Gymnastics Group Routines Clustered According to their Position in the 2010 World Championship Ranking

\begin{tabular}{|c|c|c|c|c|c|c|c|c|}
\hline & \multicolumn{3}{|c|}{ First Half in Ranking (n=96) } & \multicolumn{4}{|c|}{ Second Half in Ranking (n=30) } \\
\hline Number of Rotation Difficulties & Mean & sd & min & max & Mean & sd & min & max \\
\hline \hline Fouetté (a) & $0.85^{*}$ & 1.32 & 0.00 & 5.00 & 0.17 & 0.59 & 0.00 & 3.00 \\
\hline Rotations on flat foot (b) & $0.46^{*}$ & 0.58 & 0.00 & 2.00 & 0.80 & 0.81 & 0.00 & 3.00 \\
\hline Free leg at horizontal (c) & $0.50^{*}$ & 0.56 & 0.00 & 2.00 & 0.27 & 0.52 & 0.00 & 2.00 \\
\hline Rotations on body parts (f) & $0.20^{*}$ & 0.40 & 0.00 & 1.00 & 0.07 & 0.25 & 0.00 & 1.00 \\
\hline
\end{tabular}

${ }^{*} \mathrm{p}<0.05$

\section{Jump Difficulties}

Significant differences were found in the number of jump difficulties when we compared the routines in the first half of the ranking with those in the second half of the 2010 World Championship ranking (Table 6). The routines in the first half had a higher number of jumps in class (a) and (f) while all of the others classes of jumps were more performed in the routines of the second half (Table 6). Interestingly, we did not record any occurrence in the class of "other" jumps that includes the split and stag with change legs, scissor, enterlacé and butterfly jumps.

Moreover, we found significant differences in the technical value of jump difficulties between the routines in the first half and those ranked in second half of the 2010 World ranking (Table 7). The routines ranked in the first half had a higher difficulty values in split/stag, fouetté jumps but only the jeté with turn presented a significant differences. While the routines ranked in the second half had higher difficulty values in cossack, tuck/vertical jumps but only the arch/cabriole and pike/straddle jumps presented a significant differences.

\section{Rotations Difficulties}

There were significant differences in the number of rotation difficulties between the routines of the first half and those of the second half of the World ranking (Table 8). The routines of the first half had higher number of rotations in 
Table 9. Technical Value of Rotation Difficulties Presented in the Rhythmic Gymnastics Group Routines Clustered According to their Position in the 2010 World Championship Ranking

\begin{tabular}{|c|c|c|c|c|c|c|c|c|}
\hline & \multicolumn{3}{|c|}{ First Half in Ranking (n=96) } & \multicolumn{4}{c|}{ Second Half in Ranking (n=30) } \\
\hline Rotation Difficulties Value & Mean & sd & min & max & Mean & sd & min & max \\
\hline \hline Fouetté (a) & $0.36^{*}$ & 0.51 & 0.00 & 2.50 & 0.07 & 0.22 & 0.00 & 0.90 \\
\hline Free leg at horizontal (c) & $0.34^{*}$ & 0.39 & 0.00 & 1.20 & 0.13 & 0.24 & 0.00 & 0.70 \\
\hline
\end{tabular}

$* p<0.05$

classes (a), (c) and (f) while all of the other classes of rotations were more used in the routines of the second half of the ranking (Table 8).

Significant differences were also found in the mean technical value of the rotations used in the routines of the two subgroups. The routines of the first half had higher mean values in the classes of rotations on body parts, with free leg below horizontal but only the fouetté, and rotations with free leg at horizontal reported significant differences (Table 9). The routines of the second half, on the other hand, had a higher value in the rotations on flat foot, with free leg high, the cossack, and the rotations with shape change but without significant differences.

\section{DISCUSSION}

This study is the first to provide a quantitative and qualitative analysis of the technical difficulties used in the group routines at the 2007, 2008, 2009 and 2010 Portimão World Cup. These 126 routines were clustered into two subgroups according to their ranking at the 2010 World Championships. We found no significant differences in the number of balances, jumps and rotations performed between the routines ranked in the first, top half and those in the second, bottom half of the World ranking. In addition, rotations were less used in the group routines maybe because these are the most complex and time dependent body difficulties. This makes them more unpredictable when trying to demonstrate good synchronisation amongst five group gymnasts [5]. This supports a previous report by Ávila-Carvalho, Palomero \& Lebre [12] in a study done with group routines of 5 hoops as well as with 3 ribbons and 2 ropes. Other studies have also reported less use of rotations and balance difficulties in comparison to the other body difficulties $[8-11,13,14,16]$. However, the present study is based on the new technical framework that has eliminated the technical category of flexibility and most of these flexibility elements have been moved to the balances category. In all of Rhythmic Gymnastics competition studies [8-11, 13, 19] the jumps have been reported as the most used difficulties. In our study, jumps were the second mostly used body difficulty category independently of the routine's position in the World ranking.

The only significant differences between the routines ranked in the first versus the second half of the ranking were in the exchange difficulties. This was expected because of the higher risk of losing the apparatus. So the groups of the higher competitive level included significantly more exchanges than the weaker ones who had lower number of exchanges allowed by the FIG Code of Points [17, 18] avowing losing of apparatus risk. A similar pattern has also been reported by Sierra \& Bobo [15], the authors reported a high frequent occurrences in exchange actions. Despite the type of routine, individual versus group $[9,16]$, the apparatus used [8, 10-12], and/or performance ranking the type of body difficulties used is very similar. This limits the performance variety during the competitions. This makes the routines not only repetitive and monotonous but also very difficult to the judge.

Further analysis also showed that the routines ranked in the top half included throws of higher risk and value in the exchanges than the lower ranked routines. We also found that the better routines had significant higher value rotations than the lower level routines. The main reason for this difference could be due to the fact that is very difficult to achieve good synchronization between the five gymnasts while rotating, and it is normal that the groups of lower technical level do not choose this type of body element to perform during competitions. In fact, the more successful routines not only had higher number of exchange and rotation difficulties but also higher values in all difficulty categories.

Regarding the exchange difficulties, when we analysed the exchanges types we found no significant differences between the two subgroups in the number of exchanges performed without or with body difficulties. In addition, the exchanges with body difficulties used in our routines were similar to those reported by Ávila-Carvalho, Palomero \& Lebre [12]. Other studies reported also a higher number of actions without body difficulties in the exchange difficulties $[8,10,11,15]$. Jumps have been reported the most used body elements during exchanges $[8,11,12]$. In our study the high level routines had more jumps and rotations than the lower level routines. So, the lower level routines included exchanges involving with less displacement (linear or rotational) because stationary positions make the exchanges less risky [4].

When the balance difficulties were evaluated, we found significant differences in the types of balances used by the two subgroups. In comparison to other Rhythmic Gymnastics group composition studies [8-11] the present study also reports different predominant type of balances. According Avila-Carvalho \& Lebre [9], low amplitude balances, like on bent leg category, are more frequent in group than individual routines. Salvador [16] reported low amplitude balances used in novice and junior routines. Rhythmic Gymnastics is characterized by the spectacular amplitude and plasticity movement [20] presenting a high aesthetic component [21]. It is, therefore, logical that the best groups had more balances with high amplitude requirements than the groups in the second half of the ranking. According 
to Laffranchi [22], flexibility is the main physical quality required for the execution of most Rhythmic Gymnastics technical elements. So if a group wants to compete for a higher place in the ranking they must include balances of high amplitude in their routines. According to Hrysomallis [23], in some sports high level athletes display greater balance ability. Although we did not directly assess the balance ability of the groups, it was clear from the analysis that the best groups choose balances of higher amplitude making an effort to improve not only the difficulty but also the artistic score [14].

Considering jump difficulties, the routines in the first, top half of ranking had higher more complex jumps with a higher technical value (Jeté with turn and Fouetté jumps categories) [5]. These types of jumps with rotation place a higher demand on the gymnasts' physical preparation that require a higher training level [24]. In addition, a longer and a nonlinear jump promotes the artistic quality $[5,7]$ and it is hard to perform with apparatus work. In a study about jumps complexity Sousa \& Lebre [25] reported that better gymnasts performed higher and longer jumps. In the present study, the routines of the second half of the ranking had higher number of Cossack and Pike/Straddle jumps that do not require high amplitude and have a short horizontal trajectory $[5,24]$ so they are less demanding with apparatus work. When we analysed the technical value of the jumps, the jeté with turn class of jumps had the highest value in both subgroups. However, the groups ranked in the top half performed more jumps of high value in this class. The groups in the second half of ranking performed arch/cabriole and pike/straddle jumps of higher technical value in comparison to the groups in the first half of the ranking, which means that the weaker groups choose jumps requiring an easier execution technique [5].

When analysing the rotation difficulties, although the rotations were the body difficulty less used, it showed more variety. The better groups used more complex rotation difficulties such as the Fouetté, the free leg at horizontal and the rotation on body parts. This could be attributed to the technical preparation required for the execution of the fouetté rotations while performing rotations on the floor (rotation on body parts) requires good apparatus handling [5]. In previous studies, the fouette was the rotation mostly used in elite group routines $[8,10,11]$ but not in individual routines [26]. Other studies also reported lesser use of these rotations $[9,16]$. The rotations on flat foot as well as the rotations with free leg high were the rotations used in the lower ranked routines because are easier. Salvador [16] also reported a high number of this kind of rotations in non-elite routines.

When we analysed the technical value of the rotation difficulties used by the two subgroups we also found some significant differences. The first half ranked routines had a higher value in the fouetté and free leg at horizontal rotations that the second half ranked routines. This could mean that the better routines performed a higher number of rotations in these two types of difficulties in order to increase their value. It is risky to perform a higher number of this type of rotations because of the increased risk for mistakes and the added challenge of synchronization amongst the five gymnasts of the group [5]. Rotations on flat foot and free leg high were the ones with higher value for the routines in the second half of the ranking because mentioned before these are rotations with lower technical demands for both body and apparatus work. The present study has some limitations that should be considered. The CoP adjustments which have taken place every four years (Olympic cycle) introduce some specific changes on the competition routines and in this study we analyzed the routines in 2007 and 2008 that were prepared according to a different version of Cop than the routines from 2009 and 2010.

\section{CONCLUSION}

Body difficulties in Rhythmic Gymnastics group routines followed a pattern consistent with their ranking. The main characteristic of the routine composition was the focus on exchanges, balances and jumps and the lesser use of rotations. Amongst all body difficulties the jumps was the technical category with the most limited variety while rotations although less used had more variety. The main differences in the composition pattern between the routines in the first, top half and those in the second, bottom half of the World ranking were that the more successful routines: (i) had more and higher level exchanges and rotations; (ii) the exchanges were done in connection with body difficulties involving displacement and rotational movements; (iii) the exchanges without body difficulties were more risky; (iv) had higher balance difficulty value from the high amplitude movements, from body elements with strong technical requirement, and from elements done in coordination with complex apparatus work; (v) the difficulty value associated with jumps was mainly based on the jumps involving rotation (Jeté with turn); (vi) the difficulty value associated with rotations was mainly based on the rotations with high level technique requirement (Fouetté) and with high level apparatus work. In closing, the limited variety in the choice of body difficulties in the composition of Rhythmic Gymnastics group routines makes them monotonous and compromises their artistic value. This study provides updated information regarding the mainstream strategies in the Rhythmic Gymnastics routine composition.

\section{CONFLICT OF INTEREST}

The authors confirm that this article content has no conflicts of interest.

\section{ACKNOWLEDGEMENT}

Declared none.

\section{REFERENCES}

[1] Bauch R. Controversial Topic: "Code de Pointage". Hamburg 2001. [cited 2010 May 20]; Available from: http://www.gymmedia.com/FORUM/agforum/bauch_code_e.htm (Issue/volume)

[2] Bobo M, Sierra E. Una nueva propuesta de dificultades corporales en gimnasia rítmica deportiva. Libro de resúmenes del VI Congreso de Educación Física e Ciencias do Deporte dos Países de Lingua Portuguesa Deporte e Humanismo en clave de Futuro 1998.

[3] Lebre E. Technical principles for the new framework. Crossroads to the Future. Switzerland: International Federation of Gymnastics Scientific Commission 2011; pp. 1-8.

[4] Russel K. Fundamentos. Basic gym fundamentos da ginástica e da literacia motora. Canada: Ruschkin 2008; pp. 1-6.

[5] Nina V, Nota K, Natalia G, Daniela DC, Fink H. Groups. In: FIG, Ed. Rhythmic Gymnastics Technical Manual Level 3. Lousanne: FIG Academy 2011; pp. 3-55. 
[6] Avilés M. Algunas consideraciones acerca de la composición y montaje de los ejercicios competitivos en la Gimnasia Rítmica. 2001. [cited 2010 April 19]; Available from: http://www.efdeportes.com/efd33a/ritmica.htm

[7] Lisitskaya T. Preparación coreográfica. In: Paidotribo E, Ed. Barcelona: Gimnasia Rítmica 1995; pp. 39-64.

[8] Ávila-Carvalho L, Corte-Real A, Araújo C, Botelho M, Lacerda T, Lebre E. Difficulty score for Rhythmic Gymnastics group exercises in Portimão 2007 World Cup Series. In: Cabri FA, Araújo D, Barreiros J, Dinis J, Veloso A, Eds. Book of abstracts of the 13th Annual Congress of the European College of Sport Science. Lisbon: FMH 2008; pp. 149-50.

[9] Avila-Carvalho L, Lebre E. A dificuldade dos exercícios individuais e de conjuntos de elite de ginástica rítmica. Motricidade II Simpósio Internacional de Performance Desportiva, 2011 Oct 8$9^{\text {th }}$, Universidade da Beira Interior (Covilha) 2011; 8(S1): 77-8.

[10] Ávila-Carvalho L, Palomero MdL, Lebre E. Difficulty score for rhythmic gymnastics group routines in portimão 2008 world cup series. Motricidade 2009; 5(3): 93.

[11] Ávila-Carvalho L, Palomero MdL, Lebre E. Difficulty score in group rhythmic gymnastics. portimão 2007/2008 world cup series. Palestrica Mileniului III Civilizatie si Sport 2009; Anul X, 3(37): 261-7.

[12] Ávila-Carvalho L, Palomero MdL, Lebre E. Body difficulty score (d1) in group rhythmic gymnastics in portimão 2009 world cup series. In: FGP, Ed. Da Prática à Ciência Artigos do $2^{\circ}$ e $3^{\circ}$ Congresso de FGP. Lisboa 2011; pp. 105-13.

[13] Caburrasi EF, Santana MV. Análisis de las dificultades corporales en los campeonatos Europeos de Gimnasia Rítmica Deportiva Granada 2002. [cited 2009 December 9]; Available from: http://www.efdeportes.com/efd65/grd.htm

[14] Bobo M, Sierra E. Estudio de las repercusiones de los cambios de código de puntuación en la composición de los ejercicios de gimnasia rítmica en la técnica corporal. 2003. [cited 2011 September 3]; Available from: http://www.cienciadeporte.com/congreso $/ 04 \% 20 \mathrm{val} / \mathrm{pdf} / \mathrm{p} 3 . \mathrm{pdf}$

[15] Sierra E, Bobo M. Estudio de la variable técnica en los ejercicios de conjunto en gimnasia rítmica. Actas del Primer Congreso de la Asociación Española de Ciencias del Deporte 2000; pp. 171-80.
[16] Salvador G. Body difficulty level evaluation in individual rhythmic gymnastics routines of portuguese young and junior gymnasts (abstract only). MS Thesis. Porto: Porto University, Sports Faculty 2009.

[17] Fédération International de Gymnastique. Code of points rhythmic gymnastics: 2005-2008. Lausanne: Comité technique Gymnastique Rythmique 2005.

[18] Fédération International de Gymnastique. Group exercises. In: FIG, editor. Code de Pointage Gymnastique Rythmique: 2009-2012. Lausanne: Comité technique Gymnastique Rythmique; 2009. pp. 67-87.

[19] Ávila-Carvalho L, Leandro C, Lebre E. 2009 Portimão Rhythmic Gymnastics World Cup. Scores analysis. Book of abstracts of the 16th Annual Congress of the European College of Sport Science. Liverpool 2011; pp. 579-80

[20] Bobo M, Sierra E. Concepto e caracterización xeral. In: Lea E, Ed. Ximnasia rítmica deportiva - adestramento e competición. Santiago de Compostela1998. pp. 31-43.

[21] Santos A. Flexibility and strength in rhythmic gymnastics: portuguese gymnasts' evaluation (abstract only). MS Thesis. Porto: Porto University, Sports Faculty 2011.

[22] Laffranchi B. O treinamento de alto rendimento na ginástica rítmica. In: SportsFaculty PU, ed. Planejamento, Aplicação e Controle da preparação técnica da Ginástica Rítmica: Análise do Rendimento técnico alcançado nas temporadas de competição Sport Science PhD thesis. Porto: Porto University, Sports Faculty 2005; pp. 5-86.

[23] Hrysomallis C. Balance ability and athletic performance. Sports Med 2011; 41(3): 221-32.

[24] Lebre E, Araujo C. Técnica corporal. In: Editora P, Ed. Manual de Ginástica Rítmica. Porto: Port Editora 2006; pp. 9-85.

[25] Sousa F, Lebre E. Biomechanical analysis of two different jumps in rhythmic sports gymnastic. Proceedings of XIV symposium on biomechanics in sports; 1996 June $25^{\text {th }}-29^{\text {th }}$, Madeira-Portugal 1996; pp. 416-9.

[26] Lebre E. Estudo da dificuldade dos exercícios apresentados pelas ginastas individuais na Taça do Mundo de Portimão 2007. Actas do $2^{\circ}$ Congresso Nacional de Formação da Federação de Ginástica de Portugal 2007; pp. 301-6.

(C) Ávila Carvalho et al.; Licensee Bentham Open.

This is an open access article licensed under the terms of the Creative Commons Attribution Non-Commercial License (http://creativecommons.org/licenses/ by-nc/3.0/) which permits unrestricted, non-commercial use, distribution and reproduction in any medium, provided the work is properly cited. 